УДК 94(517.3)

ГОМБОЖАПОВ Александр Дмитриевич - кандидат исторических наук, ведущий научный сотрудник отдела истории и культуры Центральной Азии Института монголоведения, буддологии и тибетологии СО РАН (670047, Россия, Республика Бурятия, г. Улан-Удэ, ул. Сахьяновой, 6; Agoтbоzh@ gmail.com)

НОЛЕВ Евгений Владимирович - кандидат исторических наук, научный сотрудник отдела истории и культуры Центральной Азии Института монголоведения, буддологии и тибетологии СО РАН (670047, Россия, Республика Бурятия, г. Улан-Удэ, ул. Сахьяновой, 6; nolev@inbox.ru)

\title{
ОТ ВЕЛИКОЙ МОНГОЛЬСКОЙ ИМПЕРИИ К ЭПОХЕ «МАЛЫХ ХАНОВ»: ЭВОЛЮЦИЯ ПОЛИТИЧЕСКОГО ЗНАЧЕНИЯ ТИТУЛОВ МОНГОЛЬСКИХ ПРАВИТЕЛЕЙ
}

Аннотация. В статье рассматривается эволюция политического значения титулов монгольских правителей от времени становления империи Чингисхана до утраты монгольскими ханствами политической независимости.

Ключевые слова: монголоведение, Великая монгольская империя, Чингисхан, период «малых ханов»

$\mathrm{H}$ а рубеже XII-XIII вв. из некогда неустойчивой общности монгольских племен, единство которых поддерживалось этнической идентичностью, монголы стремительно эволюционировали в сторону общества с развитой политической системой, со сложной внутренней социальной структурой и, наконец, создали огромное государство-империю. В ходе данного процесса принцип распределения позиций в иерархической системе потестарной власти, детерминированный положением в генеалогии рода, уступает принципу обретения власти за счет личных качеств военных вождей в рамках так называемого харизматического типа правления. Объединение монгольских племен и потребность вести более крупные военные действия на внешних границах привели к усилению власти отдельных правителей и, как следствие, к необходимости применения титула, способного отразить происшедшие изменения. Как справедливо отмечает профессор Т.Д. Скрынникова, эта новая для общества должность получила и новое (для монгольского этноса) обозначение, уже имевшее традицию в регионе, - хан: Амбагай-хан, Хутула-хан, Чингис-хан, Джамуха-гурхан. «Принадлежа к коническому клану, они не занимали в нем лидирующего положения, но выделялись в рамках харизматического типа “господства-подчинения" и внесли коррективы в действовавшие родовые институты, не уничтожая их, а приспосабливая к изменившейся ситуации» [Скрынникова 1997: 37].

При этом процесс расширения масштабов власти хаганов в рамках конкурентной борьбы периода созидания империи сопровождался появлением дополнительных маркеров, отражающих полноту власти отдельных правителей. Так, предводитель кереитов Тогорил за победу над татарами был удостоен высокого титула вана со стороны династии Цзинь. «Узнав о смерти МегучжинСеульту, Ван-гин-чинсян очень обрадовался и пожаловал Чингисхану титул чаутхури, а Кереитскому Тоорилу - титул вана» [Сокровенное сказание... 1990: 51]. Ориенталисты склонны отождествлять титул «ван» и «царь» [Хоанг 2016: 97; Ру 2006: 111], отмечая, что, наряду с презрением к китайцам, «варвары» испытывали пиетет к китайским титулам и, получая их, очень этим гордились. 
Таким образом, титул ван-хан, заменивший на страницах летописи личное имя Тогорил-хана, являлся сочетанием правовой традиции монгольских народов и китайской инвеституры, подчеркивая внешнюю легитимацию власти кереитского правителя.

Избрание в 1201 г. Джамухи-анды (названного брата Чингисхана, ставшего впоследствии его главным политическим оппонентом) гур-ханом демонстрирует еще один вариант титула, имевшего потенциал общемонгольского значения, что подтверждается солидным представительством племен, участвовавших в собрании [Сокровенное сказание... 1990: 54]. Титул гур-хана, по мнению Б.3. Базаровой, унаследован монголами от кара-китайских правителей, имеет тюркскую основу - kül (озеро), преобразованную в кара-китайском языке в gür, и в фигуральном смысле означал «большой, великий, необъятный» [Базарова 2006: 183]. Источники сохранили свидетельства поднесения данного титула и Темуджину «синими монголами». Однако в масштабах Азии ко времени создания Монгольской империи титул гур-хана утратил былое геополитическое значение, что было обусловлено ослаблением самих каракитаев, превратившись в титул провинциальных властителей [Базарова 2006: 184-185].

Объединение монгольских племен и построение евразийской сверхдержавы объективно диктовали Темуджину необходимость принятия титула, отражающего масштабы его могущества. Этим титулом стал «чингис» (от тюркского tenggis - море), что в фигуральном смысле обозначало всеобщность и безбрежность власти хагана. Выбор именно данного титула среди известных в тот период монголам аналогов dalai (океан) и kül (озеро) Б.3. Базарова объясняет меньшим употреблением и, следовательно, большим поэтическим содержанием слова tenggis по отношению к слову dalai и на порядок большим реальным значением моря по отношению к озеру [Базарова 2006: 142]. В последнем случае нельзя не отметить и такие факторы, как ослабление геополитического значения производного титула гур-хан и использование данного титула политическими оппонентами Темуджина, что уравнивало бы носителя титула с другими вождями племенных союзов.

В историографии высказываются различные мнения относительно обстоятельств и времени принятия Темуджином титула Чингис-хан. Согласно «Сокровенному сказанию монголов», около 1180 г. Алтан, Хучар, Сача-Беки и все прочие «Темучжина же нарекли Чингисхаганом и поставили ханом над собой» [Сокровенное сказание... 1990: 45-46]. В «Истории первых четырех ханов из дома Чингисова» обретение Темуджином нового титула датируется 1206 г.: «Чингис, собрав всех князей и чиновников при вершинах Онони, выставил девять белых флагов и вступил на императорский (ханский) престол. Князья и чины поднесли ему название Чингис-Хана» [История первых... 1829: 35]. Отметим, что в исторических сочинениях встречается ретроспективная модернизация титула Чингис-хан в описании более ранних событий жизни монгольского правителя. Изучая данную особенность, Б.З. Базарова сделала обоснованное предположение, что в 1206 г. Темуджин получил титул «всеобщий великий хан» (gür yeke qaزan), который по мере расширения территории империи и усиления авторитета правителя стал «отставать» от реального статуса своего носителя. Принятие титула Чингис-хан исследователь относит ко времени монгольского завоевания государства хорезмшаха, т.е. к 1222-1224 гг., в результате которого побежденные основные и сильнейшие враги поднесли монгольскому правителю титул, равный по своей исторической значимости титулам могущественных древнетюркских ханов [Базарова 2006: 192]. 
Неоднозначна ситуация и с определением времени употребления титула хаган (qajan). В историографии сформировались две позиции на этот счет. Согласно одной из них, первым хаганом (кааном) Монгольской империи был Чингисхан. Представители альтернативной точки зрения первым хаганом называют сына и преемника Чингисхана Угедэя, объясняя употребление титула Чингис-хаган в источниках в качестве посмертного титула, храмового имени, дарованного великому правителю позднее в рамках китайской политической традиции. Профессор В.В. Трепавлов приходит к аргументированному выводу о прижизненном использовании титула хаган Чингисханом. При этом, принимая во внимание тот факт, что в степных державах хаган возглавлял обычно независимое государство, ученый предполагает связь между началом употребления данного титула и официальным разрывом с пекинским двором в 1210 г., послужившим основанием для превращения ханства-улуса в каганат [Трепавлов 1993: 61, 62]. Крупный специалист по истории монгольских народов Лоуренс Кредер, прослеживая ситуацию на материале «Тайной истории монголов», полагает, что различие в употреблении терминов хан и хаган возникло в период становления огромной Монгольской империи, т.е. на протяжении XII-XIII вв. Новая реальность - переход от политической общности номадов к обширной империи потребовала институционализации большого числа учреждений, в т.ч. утверждения нового титула. Линия Чингизидов, носивших титул хагана, подчеркивала данный факт. Правители меньшего ранга носили титул хана. Носившие данный титул не имели политического суверенитета. Он также выделяет употребление в источнике термина «хаан» (qahan). В отличие от вышеупомянутых владетельных титулов, значение термина «хаан» передает, по мнению ученого, более уважительное отношение, знак почтения [Krader 1955].

Закреплением власти представителей «золотого рода» Чингисхана было обусловлено формирование нового иерархического порядка в кочевой империи, основанного на амбивалентности соотношения власти и собственности: «с одной стороны, все права сохраняются за владельцем улуса и передаются его потомкам, а с другой - его власть перекрывается властью хагана, который являлся всесильным монархом» [Крадин, Скрынникова 2006: 377]. Данный принцип, не всегда соблюдавшийся на практике в силу ряда обстоятельств, был надежно закреплен в порядке распределения титулов. Так, например, Р.Ю. Почекаев справедливо утверждает, что Бату - правитель улуса Джучи - никогда не был ханом: он упоминается с ханским титулом только в сочинениях, появившихся гораздо позже его смерти [Почекаев 2007: 13].

Становление Юаньской династии и перенесение столицы в Ханбалык (Даду) ускорило политическую дезинтеграцию общемонгольской империи. Случившаяся коллизия с провозглашением на разных курултаях 1260 г. двух императоров стала началом серьезных противостояний в империи. Междоусобная борьба за великоханский престол (1260-1264 гг.) закончилась победой Хубилая. За императорами династии Юань со стороны правителей других улусов империи номинально сохранилось признание их великими ханами (Yeke Qaghan, ikh khaan). В историко-правовом памятнике «Чаган тэукэ» («Белая история») Хубилай-хан в рамках доктрины двух законов получает титул «Хубилай чакраварун сэчэн хаган, вращающий тысячу золотых колес учения» [Cagan teuke 2001: 73, 85]. Значение данного титула в иерархии царей в буддизме соответствует уровню вселенского, или всемирного монарха. При этом обосновывается включенность Хубилая в традицию политической и религиозной преемственности от древних царей Индии и Тибета.

В 1368 г. последний император династии Юань Тогон-Тэмур был вынужден бежать на свою историческую родину в ходе наступления войск основателя 
новой китайской династии Мин Чжу Юаньчжана на Пекин. Будучи изгнанными из Китая, монгольские правители продолжили политическую традицию, именуя себя императорами династии Юань, которая вошла в историю как династия «Северная Юань». В 1388 г. войска династии Мин нанесли сокрушительное поражение монголам около оз. Буюр-Нор, после которого они не смогли оправиться. Надежды на восстановление династии Юань в Китае были окончательно потеряны.

В конце XIV столетия на фоне политического кризиса в Восточной Монголии происходит усиление западных монголов, создавших в 1399 г. государственное объединение, известное как Дербен Ойрат (Dörben Ö̈rd). Борьба двух конфедераций - собственно ойратского союза и восточномонгольских князей - отразила новую политическую ситуацию в степи. На политической арене главными действующими лицами стали представители наследственной знати. В этот период противоборства «великие ханы» обладали лишь номинальной властью, в то время как власть реальная принадлежала аристократии. Тем не менее, как отмечает Т. Барфилд, «китайцы, имевшие склонность внимательно следить за “легитимным” родом, часто заблуждались относительно роли этих номинальных ханов в степной политике, детально фиксируя все их возвышения, правления, убийства и смещения. Монголы, видимо, отчасти сами давали повод для подобных подозрений со стороны Мин, поскольку присваивали своим ханам царские имена на китайский манер. Однако они, вероятно, делали это по традиции, без скрытого умысла - по той же самой причине, по которой продолжали использовать титулы, принятые среди чиновников в империи Юань» [Барфилд 2009: 186].

Как известно, претендентом на великоханский престол мог быть только представитель линии Чингизидов, так же как право инвеституры принадлежало лишь «золотому роду». Не решаясь прервать традиции политической преемственности, монгольская знать поддерживала угодных ей представителей династийного рода. Это привело к довольно частой смене правителей на великоханском престоле, что, безусловно, обесценивало сам титул общемонгольского хагана. И все же в ходе этой борьбы происходили случаи, когда великим ханом, например, стал Гуйличи, или Оруг-тэмур (1402-1408 гг.), не принадлежавший к так называемому золотому роду Чингизидов.

Длительное противостояние между аристократией западных и восточных монголов, вылившееся в ряд острых военных конфликтов, было прервано усилением позиций ойратской знати. Тогон-тайши удалось сосредоточить в своих руках всю полноту власти и стать фактически единоличным правителем всего монгольского мира. Крупные успехи его сына Эсэн-тайши позволили ему принять титул великого общемонгольского хана. Однако это нарушение традиции вызвало серьезное сопротивление со стороны восточномонгольских князей, переросшее в открытое противостояние.

Подлинное возвышение великоханской власти произошло в период правления Даян-хана, которому удалось преодолеть внутренние разногласия и объединить монгольскую степь в единых руках. Титул великого хана вновь был наделен полнотой реальной власти. Однако после смерти Даян-хана его владения были поделены между одиннадцатью его сыновьями, отдельные из которых провозгласили себя ханами. Таким образом, после Даян-хана Монголия распалась на несколько ханств [Шара Туджи 1957: 189].

В дальнейшем на протяжении XVI в. происходит снижение влияния великого хана на общемонгольские дела, а власть его все больше ограничивается собственным уделом. Нарастание процессов политической децентрализации, а также проводимая династией Мин пограничная политика даннической зави- 
симости привела к тому, что монгольский мир был окончательно фрагментирован. Со времен Алтан-хана Тумэтского власть общемонгольского хагана окончательно утратила былое величие.

Выдающийся ученый-монголовед Н.П. Шастина в комментарии к титулу «шитну-хан», употребленного в нескольких монгольских источниках (Шаратуджи, Эрденийн-Тобчи Саган Сэцэна), пишет, что «неясность в употреблении данного титула говорит о происшедших изменениях в Монголии, где с середины XVI века появляются одновременно несколько ханов. Значение великого хана упало, что свидетельствует об ослаблении ханской власти и усилении феодальной раздробленности. Вероятно, именно с этого времени стирается разница в употреблении терминов «хаган» (т.е. хан, обладающий верховной властью императора) и «хан» (т.е. местный, или удельный хан)» [Шара Туджи 1957: 189].

Титул великого хана стал передаваться по линии старшего сына Даян-хана и не выходил за пределы круга правителей Чахарского ханства. Формально существовавший титул великого хагана был окончательно ликвидирован с поражением Лигдэн-хана в борьбе с маньчжурами. Яшмовая печать как символ государственной власти императоров династии Юань была передана маньчжурскому предводителю Абахаю.

Статья подготовлена в рамках государственного задания ФАНО России (проект ХІІ.191.1.2. «Межкультурное взаимодействие, этнические и социально-политические процессы в Центральной Азии», номер госрегистрации № $A A A A-A 17-117021310264-4)$.

\section{Список литературы}

Базарова Б.3. 2006. Монгольские летописи - памятники культуры. М.: Academia. 368 c.

Барфилд Т.Д. 2009. Опасная граница: кочевые империи и Китай (221 г. до н.э. 1757 г. н.э.). СПб: Факультет филологии и искусств СПбГУ. 488 с.

История первых четырех ханов из дома Чингисова (пер. с кит. Н.Я. Бичурина). 1829. СПб: Типография Карла Крайя. 457 с.

Крадин Н.Н. Скрынникова Т.Д. 2006. Империя Чингис-хана. М.: ИФ «Восточная литература» РАН. 577 с.

Почекаев Р.Ю. 2007. Батый. Хан, который не был ханом. М.: АСТ Москва; СПб: Евразия. 350 с.

Ру Ж.-П. 2006. История империи монголов. Улан-Удэ: Изд-во Бурятского государственного университета. 672 с.

Скрынникова Т.Д. 1997. Харизма и власть в эпоху Чингис-хана. М.: ИФ «Восточная литература» РАН. 216 с.

Сокровенное сказание монголов (пер. С.А. Козина). 1990. Улан-Удэ: Бурятское книжное издательство. 138 с.

Трепавлов В.В. 1993. Государственный строй Монгольской империи ХІІІ в.: Проблема исторической преемственности. М.: Наука; ИФ «Восточная литература». $168 \mathrm{c}$.

Хоанг М. 2016. Чингисхан. М.: Молодая гвардия. 276 с.

Шара Туджи: монгольская летопись XVII века (свод. текст, пер., введ. и примеч. Н.П. Шастиной). 1957. М.; Л.: Изд-во АН СССР. 199 с.

Cagan teuke - «Белая история»: монгольский историко-правовой памятник XIII-XVI вв. (сост. Ц.П. Ванчикова, П.Б. Балданжапов). 2001. Улан-Удэ: Изд-во БНЦ СО РАН. 200 c. 
Krader L. 1955. Qan-Qayan and the Beginnings of Mongol Kingship. - Central Asiatic Journal. Vol. 1. P. 17-35.

GOMBOZHAPOV Aleksandr Dmitrievich, Cand.Sci. (Hist.), Leading Researcher of the Institute for Mongolian, Buddhist and Tibetan Studies, Siberian branch of Russian Academy of Sciences (6 Sah'janovoj St, Ulan-Ude, Republic of Buryatia,670047, Russia; Agombozh@gmail.com)

NOLEV Evgeniy Vladimirovich, Cand.Sci. (Hist.), Researcher of the Institute for Mongolian, Buddhist and Tibetan Studies, Siberian branch of Russian Academy of Sciences (6 Sah'janovoj St, Ulan-Ude, Republic of Buryatia, Russia, 670047; nolev@inbox.ru)

\section{FROM THE GREAT MONGOL EMPIRE TO THE ERA OF MONGOL KHANATES: EVOLUTION OF THE POLITICAL SIGNIFICANCE OF TITLES OF MONGOL RULERS}

Abstract. The article represents a historical review of the works devoted to the ruler's titles of the Great Mongol Empire and Mongol khanates of post Yuan period. The authors presented the evolution of the political significance of titles of qayan, qan and qaan in the state of Genghis Khan and states of his successors. They pay special attention to the research of the theoretical foundation of historical concepts of supreme authority in Mongolian medieval political system in the domestic and foreign historiography.

Keywords: Mongolian studies, Great Mongol Empire, Genghis Khan, Mongol khanates of post Yuan period 